\title{
Review: Marsh rosemary (Rhododendron tomentosum Harmaja (ex Ledum palustre Linn) growing in Lithuania) essential oils and their properties
}

\author{
Asta Judžentienė ${ }^{*}$ \\ Department of Organic Chemistry, \\ Center for Physical Sciences \\ and Technology, \\ 3 Sauletekio Avenue, \\ 10257 Vilnius, Lithuania
}

The paper reviews already (in the past fifteen years) published data from research articles on essential oils (EOs) and their biological properties (such as antioxidant, antifungal, anti-inflammatory and toxic activity) of marsh rosemary (Rhododendron tomentosum (Stokes) Harmaja (ex Ledum palustre Linnaeus, Ericaceae Juss.) growing wild in Lithuania.

$R h$. tomentosum is a perennial woody shrub (up to $1 \mathrm{~m}$ in height) with evergreen leaves and small white or white-pink sticky flowers grouped in racemes. The plant emits a strong specific smell that affects the central nervous system, and may cause nausea, headache or aggressive behaviour to some people. Only one species of the plant (ex L.palustre var.palustre) grows in Lithuania, mainly forming colonies in limited areas over all the territory.

Marsh rosemary are widely used in folk medicine and homeopathy for treatment of various sickness, externally and internally as well. Most applications of $R h$. tomentosum and pharmacological properties have been validated by scientific researches. In Lithuania, the plant is used for healing rheumatism, different pains, insect bites, eczema and other skin problems, infections, bronchitis, asthma, cold, tuberculosis, to block bleeding, etc.

Rhododendron tomentosum $\mathrm{H}$. (ex Ledum palustre L.) plants, the essential oils (EOs) of which are already investigated, were collected mostly in the Eastern part of the country (Rokiškis, Utena, Vilnius and Šalčininkai districts). Monoterpene hydrocarbons, p-cymene, myrcene and limonene, bicyclic monoterpenoid ascaridole and oxygenated sesquiterpenes, ledol, palustrol and cyclocolorenone isomers, were found to be principal compounds in the investigated EOs. Some oils contained appreciable quantities of heterocyclic compound lepalol. Most of the oils could be attributed to the ledol+palustrol or ledol+palustrol+ascaridole chemotype.

Antifungal activity of Rh. tomentosum EOs was evaluated by several different techniques: against Penicillium cyclopium Westling, Trichoderma harzianum Rifai and Candida parapsilosis using an agar diffusion method; and amperometricaly, using Saccharomyces cerevisiae yeast-modified electrodes.

Anti-inflammatory activity of Lithuanian marsh rosemary EOs has been revealed by subcutaneous carrageenan injection-induced hind paw oedema tests.

However, antioxidant activity (tests using $\mathrm{ABTS}^{-+}, \mathrm{DPPH}^{*}$ and TROLOX) and toxic properties (against brine shrimp (Artemia sera) larvae) of Rh. tomentosum EOs were summarized.

Keywords: Rhododendron tomentosum H., Ericaceae, essential oil composition, ledol, palustrol, ascaridole, cyclocolorenones, antifungal activity, antioxidant tests, antimicrobial properties, toxicity in vivo

\footnotetext{
"Corresponding author. Email: asta.judzentiene@ftmc.lt
} 


\section{INTRODUCTION}

Rhododendron tomentosum (Stokes) H. Harmaja (formerly mostly known as Ledum palustre Linnaeus, Ericaceae Juss.) is a perennial woody shrub (up to $1 \mathrm{~m}$ in height) with evergreen leaves and small white or white-pink sticky flowers grouped in racemes. The flowering period is from April to August, depending on the geographical area. The plant is called commonly as a marsh rosemary, marsh tea or marsh Labrador tea. Its names suggest (including the Lithuanian name Pelkinis gailis) that for the plant it is most appropriate to grow in marshy and swampy areas. The preferred growing habitats are peaty and acidic soils, with various sun illuminations. Wild populations of marsh rosemary are found in Northern and Central Europe, Northern Asia (China, Korea and Japan) and N. America. Only one species of the plant (ex L. palustre var. palustre) grows in Lithuania [1], mainly forming colonies in limited areas over all the territory: in marshes, pinewoods, and in the forests on the Baltic seashore.

Preparations of marsh rosemary are widely used in folk medicine and homeopathy for treatment of various sickness, externally and internally as well. A long list of traditional uses has been presented in a review article of Popescu and Kopp (2013) [2].

In Lithuanian folk medicine, decoctions, alcoholic extracts or crushed raw material of the plant are used for healing rheumatism, podagra, gout, different pains, to block bleeding, insect bites, eczema and other skin problems, infections, bronchitis, pertussis, asthma, cold, cough, tuberculosis, enterocolitis, etc. In ancient times, marsh rosemary leaves were used for bear preparation instead of hops.

All parts of marsh rosemary synthesize a high content of poisonous terpenoids and emit a strong characteristic smell, which attracts bees and other pollinating insects. Flavour of the plant possesses repellent properties effective against bedbugs, clothing moths and cockroaches. The strong specific smell affects the central nervous system, and may cause nausea, headache or aggressive behaviour to some people.

The most applications of $R h$. tomentosum in folk medicine and pharmacological properties have been defined on the basis of the current scientific researches [3, 制.

Many research works have been devoted to investigate various bioactivities, such as antibacte- rial, anticancer, anti-inflammatory, fungicidal, antioxidant, toxic, etc. properties of marsh rosemary extracts (see Table 1 for details) [5-22]. The expectorant and antitussive effect of marsh rosemary tea depends on the presence of ledol in the essential oils [3]. Extracts of aerial parts of Rh. tomentosum and Archangelica officinalis exhibited radioprotective properties in vivo, using albino mongrel male mice irradiated with $\gamma$-irradiation [23, 24]. According to some literature sources, marsh rosemary extracts or emitted volatiles influence herbivores behaviour [25-29]. Repellent activity was evaluated against host-seeking nymphs of Ixodes ricinus L. [25] and mosquitoes Aedes aegypti L. [26], repellence and antifeedant effects were tested against Hylobius abietis L. and Phyllodecta laticollis Suffrian [28]. Insect growth regulating and toxic properties were investigated on the metamorphosis stages of Tenebrio molitor pupae [27]. However, compounds from marsh rosemary extracts have impact on polypropylene plastic degradation [30].

The paper reviews already (in the past fifteen years) published data from research articles on essential oils (EOs) and their biological properties (such as antioxidant, antifungal, anti-inflammatory and toxic activity) of marsh rosemary (Rhododendron tomentosum Harmaja (ex Ledum palustre Linn)) growing wild in Lithuania.

\section{CHEMICAL VARIABILITY OF THE ESSENTIAL OILS OF MARSH ROSEMARY (RHODODENDRON TOMENTOSUM HARMAJA (EX LEDUM PALUSTRE LINN)) OF LITHUANIAN ORIGIN}

\section{PLANT MATERIAL}

Rhododendron tomentosum H. (ex Ledum palustre L.) plant material, the essential oils of which are already investigated [13, 31-34], was collected mostly in the Eastern part of the country (Rokiškis, Utena, Vilnius and Šalčininkai districts), and in one study [16] a sampling site was not indicated (Fig. 1). Biological identification of most of the herbal samples and storage of voucher specimens has been performed in the Herbarium of the Institute of Botany, Nature Research Centre (BILAS), Lithuania. One Lithuanian $\mathrm{Rh}$. tomentosum herbal voucher was deposited in the Herbarium of the Faculty of Pharmacy, Monastir, Tunisia [16]. 


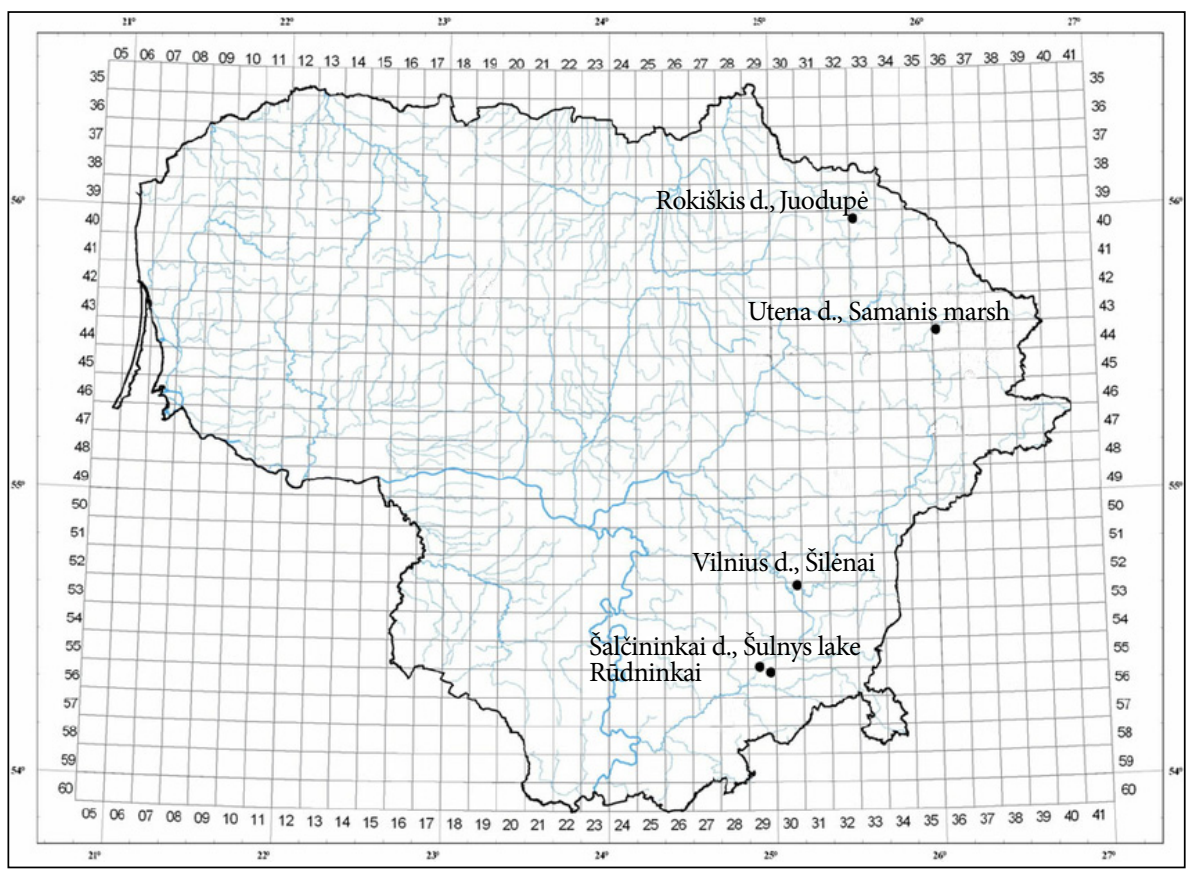

Fig. 1. Geographical distribution of sampling sites (in Lithuania) of Rhododendron tomentosum $\mathrm{H}$. plants, whose EOs are already investigated

Table 1. Already scientifically improved biological properties of $R$ h. tomentosum Harmaja (ex Ledum palustre L.) extracts, essential oils or emitted volatiles

\begin{tabular}{|c|c|}
\hline Biological activity, method applied & Literature source \\
\hline Anticancer in vitro, using mouse leukemia cells L1210 & [5] \\
\hline Anticancer in vitro, using human lympho-blastoid Raji cells & [6] \\
\hline Analgesic, using model of acetic acid-induced writhing response in mice & [7] \\
\hline $\begin{array}{l}\text { Antibacterial in vitro, by broth dilution method, against Staphylococcus aureus, Escherichia coli, Pseudo- } \\
\text { monas aeruginosa and Klebsiella pneumoniae }\end{array}$ & {$[8]$} \\
\hline $\begin{array}{l}\text { Antidiabetic in vitro, using } \mathrm{C} 2 \mathrm{C} 12 \text { murine skeletal myoblasts and the 3T3-L1 murine preadipocyte cell } \\
\text { lines }\end{array}$ & [9] \\
\hline $\begin{array}{l}\text { Antidiabetic in vitro, using Caco-2/15 cells; western blot analysis in vivo. Rats, oral glucose tolerance } \\
\text { test }\end{array}$ & {$[10]$} \\
\hline $\begin{array}{l}\text { Antifungal, against Aspergillus niger, Candida albicans, Microsporum canis, Trichophyton rubrum and } \\
\text { Trichophyton mentagrophytes }\end{array}$ & [11] \\
\hline $\begin{array}{l}\text { Antifungal in vitro, by microbroth dilution method, against Cryptococcus neoformans, Saccharomyces } \\
\text { cerevisiae, Aspergillus niger and Candida albicans }\end{array}$ & [12] \\
\hline Antifungal, using agar disc diffusion assay, against Candida parapsilosis & [13] \\
\hline Antifungal, using mediated amperometry at Saccharomyces cerevisiae-modified electrodes & [13] \\
\hline Antifungicidal, by agar-diffusion method, against Trichoderma harzianum and Penicillium cyclopium & {$[14,15]$} \\
\hline Anti-inflammatory, by model of lambda-carrageenan-induced paw edema in mice & [7] \\
\hline Anti-inflammatory in vivo, using tests of carrageenan-induced edema in rats & [8] \\
\hline $\begin{array}{l}\text { Anti-inflammatory, using tests of subcutaneous carrageenan injection-induced hind paw oedema in } \\
\text { rats }\end{array}$ & [16] \\
\hline Anti-inflammatory in vitro, by prostaglandin biosynthesis assay; PAF-induced exocytosis & [17] \\
\hline $\begin{array}{l}\text { Antimicrobial in vitro, against Staphylococcus aureus, Streptococcus pneumoniae, Clostridium perfrin- } \\
\text { gens, Bacillus cereus, Enterobacter aerogenes, Klebsiella pneumoniae, Candida albicans, Mycobacterium } \\
\text { smegmatis, Acinetobacter Iwoffii and Candida krusei }\end{array}$ & [18] \\
\hline
\end{tabular}


Table 1. (Continued)

\begin{tabular}{|c|c|}
\hline Biological activity, method applied & Literature source \\
\hline Antimicrobial in vitro, against pandemic strain Vibrio parahaemolyticus & [19] \\
\hline Antioxidant activity in vitro, by DPPH assay, ascorbic acid was used as the reference antioxidant & [10] \\
\hline Antioxidant, using radical scavenging $\mathrm{ABTS}^{+}{ }^{+}, \mathrm{DPPH}$ and TROLOX equivalent assay & [13] \\
\hline $\begin{array}{l}\text { Antioxidant in vitro, by DPPH assay, } \mathrm{Fe}^{3+}-\mathrm{EDTA}-\mathrm{H}_{2} \mathrm{O}_{2} \text { deoxyribose assay, nonenzymatic lipid peroxida- } \\
\text { tion of rat liver homogenate }\end{array}$ & [18] \\
\hline $\begin{array}{l}\text { Anti-proliferative and proapoptotic activity in vitro, the influence of EOs on blood lymphocytes' prolif- } \\
\text { eration and apoptosis rates of synovia-derived cells was determined by flow cytometry method }\end{array}$ & [20] \\
\hline Antithrombin & [5] \\
\hline Antithrombin in vitro, using thrombin solution from bovine plasma & [6] \\
\hline Hepato-protective in vivo, in rats and mice, $\mathrm{CCl} 4$ intoxication & [21] \\
\hline Toxicity in vivo, tested on mice & [22] \\
\hline Toxicity in vivo, tested on brine shrimp (Artemia sera) larvae & [13] \\
\hline
\end{tabular}

Variuos parts of the plant - all aerial parts or separated shoots, inflorescences and seeds - have been chosen for the oils preparation. Plant material was dried at room temperature $\left(20-25^{\circ} \mathrm{C}\right)$; different plant organs were separated before drying.

\section{ESSENTIAL OIL PREPARATION}

Hydrodistillation (HD) was performed in a circulatory Clevenger-type apparatus, according to the procedure described in the European Pharmacopoeia. In order to obtain sufficient amounts of wild rosemary EOs, HD time of $2 \mathrm{~h}$ was chosen [13, 31-34, and the procedure time of $4 \mathrm{~h}$ up to exhaustion of all oils present in the matrix [16]. Previously, it was proved that the extension of distillation time from 2 to $4 \mathrm{~h}$ has increased $R h$. tomentosum oil yield without significant changes in the composition of the oils [35]. Obtained EO is as yellow-grey, greasy mass with a sweet characteristic odour.

Supercritical $\mathrm{CO}_{2}$ extraction (SFE) of $R$ h. tomentosum herbal material was performed in a laboratory apparatus, working at 90 bar and $40^{\circ} \mathrm{C}$ in the extraction vessel, at 90 bar and $10^{\circ} \mathrm{C}$ in the first separator and at 20 bar and $15^{\circ} \mathrm{C}$ in the second one [16]. The extraction procedure was carried out in a semi batch mode: batch charging of vegetable material and continuous flow of solvents.

The content of EO from Lithuania marsh rosemary aerial parts varied from 0.45 to $2.01 \%(\mathrm{v} / \mathrm{w}$, on a dry weight basis). The lowest contents 0.45 and $0.59 \%$ of the oils were obtained for aged (mature) shoots gathered in Rokiškis District [31], and from young shoots collected in April in Samanis for- est marshes (Utena District), respectively [13, 32]. The largest quantity $(2.0 \%)$ of the EO was obtained after $4 \mathrm{~h}$ of a hydro-distillation procedure [16]. The yields of $R h$. tomentosum EOs varied significantly (almost 3-fold) depending on the plant vegetation stage. The oil yields changed during plant growing stages: maximum values 1.73 and $1.76 \%(\mathrm{v} / \mathrm{w})$ were determined in June and July (at the end of flowering), respectively. Thereafter, the yields decreased to $1.36 \%(\mathrm{v} / \mathrm{w})$ in October, at the full seeding stage 13 , 32. The quantity of $0.9 \%(\mathrm{v} / \mathrm{w})$ of the EO was isolation from seeds [34]. Significant differences (from 2.8 - to 4.5 -fold) were found between the minimum and the maximum yields of the investigated essential oils [13, 16, 31-34].

Variability in the content of EOs could be explained also by growing conditions, temperature, sun illumination intensity and duration of isolation procedure as well.

\section{MAIN COMPOSITION OF RHODODENDRON TOMENTOSUM HARMAJA (EX LEDUM PALUSTRE LINN) ESSENTIAL OILS}

Constituents with 2,6-dimethyloctane, menthane and aromadendrane skeletons are major and characteristic compounds for the EOs of marsh rosemary of the Lithuanian origin (Fig. 2).

Monoterpene hydrocarbons: p-cymene, myrcene and limonene, bicyclic monoterpenoid ascaridole and oxygenated sesquiterpenes: ledol, palustrol, and cyclocolorenones were determined as principal compounds in the investigated Lithuanian Rh. tomentosum EOs (Table 2). The structure 


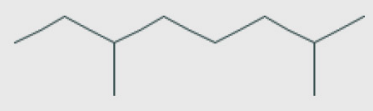

2,6-Dimethyloctane

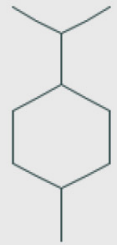

Menthane

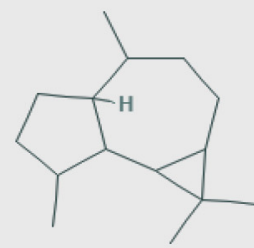

Aromadendrane

Fig. 2. Main carbon skeletons of Rhododendron tomentosum H. (Lithuanian origin) essential oil constituents

Table 2. Main constituents (\%) of $R h$. tomentosum Harmaja (Lithuanian origin, ex Ledum palustre L.) essential oils from already published data

\begin{tabular}{|c|c|c|c|c|c|c|c|c|c|}
\hline $\begin{array}{l}\text { Location, } \\
\text { Reference }\end{array}$ & No. in BILAS & $\begin{array}{l}\text { Plant organ, E0 } \\
\text { content, } \%\end{array}$ & Ledol & Palustrol & $\begin{array}{l}\text { iso- } \\
\text { Ascari- } \\
\text { dole }\end{array}$ & $\begin{array}{c}\mathbf{p -} \\
\text { Cymene }\end{array}$ & Myrcene & Limonene & $\begin{array}{l}\text { Cyclocol- } \\
\text { orenones }\end{array}$ \\
\hline $\begin{array}{c}\text { Juodupé, } \\
\text { Rokiškis d. [31] }\end{array}$ & not indicated & $\begin{array}{l}\text { Young and aged shoots, } \\
0.45-2.01\end{array}$ & $23.9-30.8$ & $35.2-42.8$ & 0.1 & tr. -0.3 & $5.7-8.6$ & $\begin{array}{c}\text { not } \\
\text { indicated }\end{array}$ & $5.0-9.3$ \\
\hline $\begin{array}{c}\text { Šilènai, Vilnius } \\
\text { d. [31] }\end{array}$ & not indicated & $\begin{array}{c}\text { Young and aged shoots, } \\
0.55-1.52\end{array}$ & $23.63-0.5$ & $31.4-36.7$ & $0.2-0.3$ & 0.1 & $1.2-6.1$ & $3.7-11.0$ & $4.0-5.3$ \\
\hline $\begin{array}{l}\text { Samanis forest, } \\
\text { Utena d. [32] }\end{array}$ & 68889 & $\begin{array}{l}\text { All aerial parts from } \\
\text { April to October col- } \\
\text { lected at the same day } \\
\text { of month }\end{array}$ & $21.0-32.3$ & $26.2-37.9$ & $\operatorname{tr} .-14.2$ & $0.2-5.0$ & $0.4-11.4$ & $\begin{array}{l}\text { below } \\
\text { detection } \\
\text { limits }\end{array}$ & $2.7-6.5$ \\
\hline $\begin{array}{l}\text { Šulnys Lake, } \\
\text { Šalčininkai d. } \\
\text { [33 ] }\end{array}$ & $68886-68888$ & $\begin{array}{l}\text { All aerial parts dur- } \\
\text { ing flowering, not } \\
\text { indicated }\end{array}$ & $5.2-23.4$ & $1.2-31.8$ & $16.7-20.5$ & $6.2-20.3$ & $0.1-1.0$ & $0-0.9$ & $0.1-2.0$ \\
\hline $\begin{array}{l}\text { Samanis forest, } \\
\text { Utena d. [13] }\end{array}$ & 68889 & $\begin{array}{l}\text { All aerial parts, col- } \\
\text { lected every month } \\
\text { from April to 0ctober, } \\
0.59-1.76\end{array}$ & $\begin{array}{l}18.0 \pm 2.9- \\
29.0 \pm 5.0\end{array}$ & $\begin{array}{c}24.6 \pm 2.6- \\
33.5 \pm 4.4\end{array}$ & $\begin{array}{l}0.1 \pm 0.1- \\
14.0 \pm 2.4\end{array}$ & $\begin{array}{c}0.2 \pm 0.2- \\
4.8 \pm 0.2\end{array}$ & $\begin{array}{l}0.4 \pm 0.1- \\
10.1 \pm 1.3\end{array}$ & $\begin{array}{c}\text { not } \\
\text { indicated }\end{array}$ & $\begin{array}{c}2.7 \pm 0.5- \\
6.2 \pm 0.3\end{array}$ \\
\hline $\begin{array}{c}\text { Rūdninkai, } \\
\text { Šalčininkai d. } \\
\text { [34] }\end{array}$ & 68890 & Seeds, 0.9 shoots, 1.5 & $\begin{array}{l}\text { In seed E0: } \\
27.0 \text {, in shoot } \\
\text { E0: } 36.5\end{array}$ & $\begin{array}{l}\text { In seed E0: } \\
\text { 38.3, in shoot } \\
\text { E0: } 21.0\end{array}$ & $0.7-5.0$ & $1.7-2.2$ & $0.4-1.9$ & $\begin{array}{l}\text { below } \\
\text { detection } \\
\text { limits }\end{array}$ & $2.1-3.5$ \\
\hline $\begin{array}{c}\text { Not indicated } \\
{[16]}\end{array}$ & $\begin{array}{l}\text { 168, Herbarium } \\
\text { in the Faculty } \\
\text { of Pharmacy, } \\
\text { Monastir, Tunisia }\end{array}$ & $\begin{array}{c}\text { Aerial parts, by } \\
\text { SFE }-1.5, \text { by }-2.0\end{array}$ & $23.3-26.7$ & $41.0-43.4$ & $4.5-15.1^{*}$ & $0.9-1.3^{* *}$ & $0.5-0.9$ & tr. -0.7 & $3.0-4.8$ \\
\hline
\end{tabular}

d., district; $\mathrm{HD}$, hydrodistillation; $\mathrm{SFE}$, supercritical $\mathrm{CO}_{2}$ extraction.

${ }^{*}$ According to the authors [16], identified compound is ascaridole.

** According to the authors [16], identified constituent is 0-cymene.

of main constituents is presented in Fig. 3. Most of the oils could be attributed to the ledol+palustrol or ledol+palustrol+ascaridole chemotype. It should be mentioned that the ledol+palustrol chemotype is common for the EOs of Rh. tomentosum plants of the European and Asian origin. Ascaridole (organic peroxide) has been identified as a predominant compound in the marsh rosemary growing in some countries, such as Finland and Sweden [26, 35]. Mono- terpene myrcene has been determined among main constituents or even the first major one in $R h$. tomentosum EOs from other world countries (Sweden, Finland, Estonia, Russia (Tomsk region) and China) [25, 35-37, 39]. Marsh rosemary oils with the predominant compound p-cymene were evaluated also in some countries (Finland, Northest China, etc.) [35, 38, 39]. Monoterpene limonene is quite rare as the major constituent in the EOs of Rh. tomentosum. 


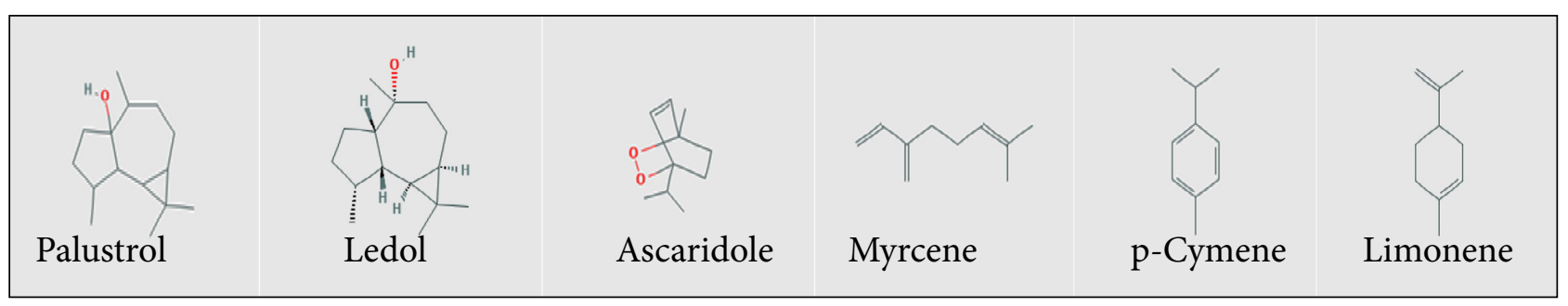

Fig. 3. Structures of the main constituents (taken from National Library of Medicine, National Center for Biotechnology Information, https:// pubchem.ncbi.nIm.nih.gov) present in Rh. tomentosum Eos (coloured online)

Limonene, p-cymene and myrcene were determined in appreciable quantities in the oils of the plants collected in the Southern regions of Tomsk, Transbaikalia and Amur Province, and also from the Southern part of the Island of Sakhalin [40]. Cyclocolorenone derivatives were identified as the dominating constituents in marsh rosemary plants of the Russian origin (Leningrad Region) [41]. Some investigated $R h$. tomentosum EOs of the Lithuianian origin were characterized by appreciable amounts of the specific constituents, furyl containing compounds, such as lepaline (3-(4-methyl)-1,4-pentadienyl) furan), lepalone (5-(3-furyl)-2-methyl-1-penten-3-one), lepalol (5-(3-furyl)-2-methyl-1-penten-3-ol) and 2-methyl-5-(3-furyl)-3-penten-2-ol [13, 32, 34]. Quantities of the heterocyclic compound lepalol reached up to $7.9 \pm 0.3 \%$ of the total oil content in some studies [13, 32].

\section{BIOLOGICAL PROPERTIES OF MARSH ROSEMARY (RHODODENDRON TOMENTOSUM HARMAJA (EX LEDUM PALUSTRE LINN), LITHUANIAN ORIGIN)}

\section{ANTIFUNGAL ACTIVITY}

Antifungal activity of $R h$. tomentosum EOs was evaluated by several different techniques: against Penicillium cyclopium Westling, Trichoderma harzianum Rifai, using an agar diffusion method [14, 15|; against pathogenic yeast Candida parapsilosis in agar disc diffusion assay [13]; and amperometrically, using Saccharomyces cerevisiae yeast-modified electrodes [13].

\section{$R h$. tomentosum EOs activity against}

\section{Trichoderma harzianum and Penicillium} cyclopium

A strong antifungal activity of $R h$. tomentosum EOs was evaluated against Trichoderma harzianum Rifai and also Penicillium cyclopium. Growth of the mitosporic fungus $T$. harzianum was inhibited by all investigated $R h$. tomentosum essential oils, obtained from the plants (from Utena District) of various vegetative stages and different organs (shoots and flowers) [14, 15]. The EOs suppressed totally the development of this fungus after seven days.

A little weaker (comparing with T. harzanum) antifungal activity was observed against $P$. cyclopium using flower marsh rosemary oils. The oil influenced fungus growth only during the first three days, while its influence decreased after seven days. Only two shoot oils (gathered in July and August, Fig. 4.3, 4.4) containing, despite principal compounds ledol and palustrol, appreciable amounts of iso-ascaridole $(14.0 \pm 2.4$ and $12.7 \pm 2.0 \%$, ) and p-cymene $(4.0 \pm 0.4$ and $4.8 \pm 0.2 \%)$ completely suppressed growth of $P$. cyclopium.

The study has confirmed that $R h$. tomentosum EOs can find practical application as a growth inhibitor of some micromycetes [14].

\section{Antifungal activity of $R \boldsymbol{h}$. tomentosum EOs against Candida parapsilosis}

An agar disc diffusion assay against the pathogenic yeast Candida parapsilosis (CBS 883C) was evaluated; and the data from this experiment revealed the potential antifungal activity of marsh rosemary EOs [13]. The filter paper discs were impregnated with $10 \mu \mathrm{L}$ of diluted EO and nystatin (an agent used to treat Candida infections) as a positive control reagent. The inoculated Petri plates were incubated at $30^{\circ} \mathrm{C}$ for $48 \mathrm{~h}$, the inhibition zone around an EO-impregnated paper disc was found to be three-fold larger compared to that around a commercial nystatin-impregnated paper disc. However, the density of the $C$. parapsilosis lawn in a plate containing EO was lower than in the plate with nystatin, indicating the suppressing effect of EO vapours on the pathogenic fungi growth [13]. 


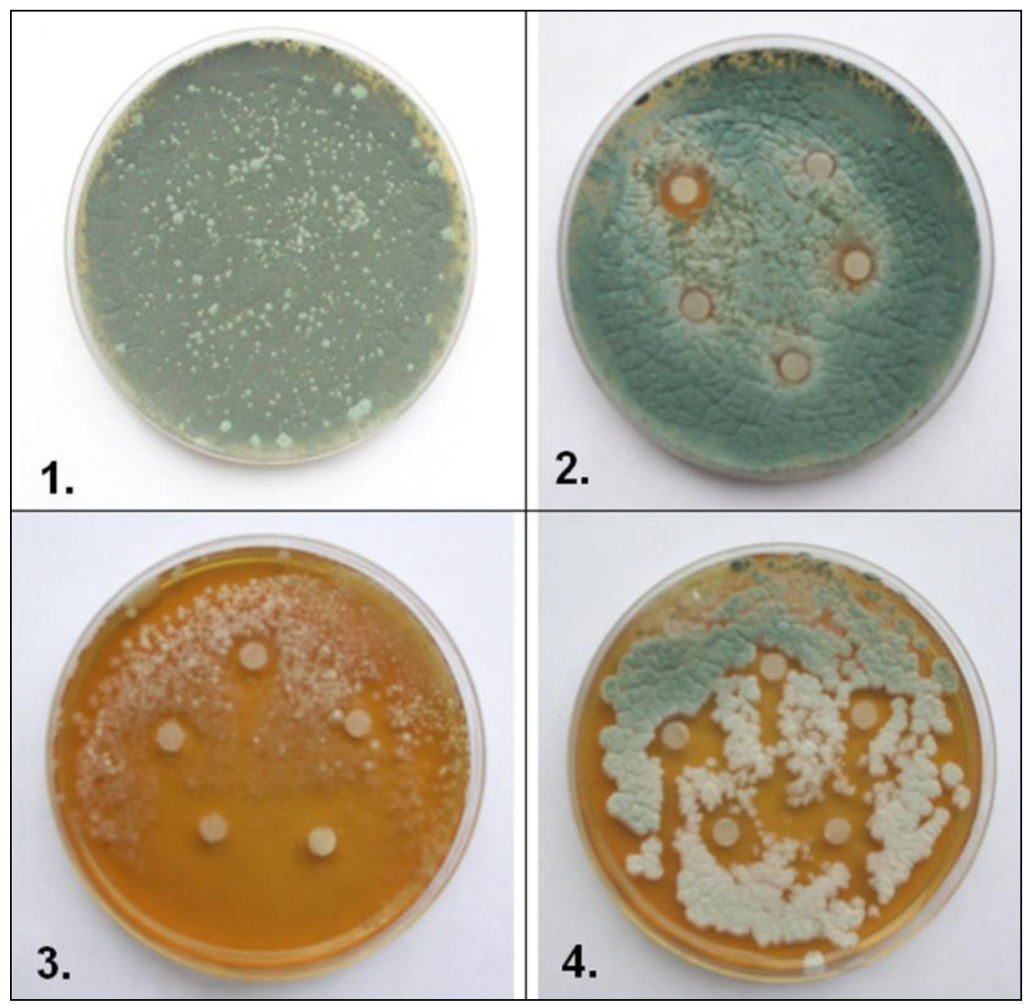

Fig. 4. Petri plates with Penicillium cyclopium transferred on agar medium; and five spots of $R$ h. tomentosum EOs (plates 2,3,4) after 7 days $[14,15]$. The pictures have been taken from a poster presentation [15] (coloured online)

Antifungal activity: $R$ h. tomentosum EOs impact on yeast (Saccharomyces cerevisiae) membranes Antifungal activity of EOs was investigated by mediated amperometry at yeast Saccharomyces cerevisiae-modified electrodes [13]. The effect of the essential oil on yeast membrane permeability was monitored by comparing the current responses to lactic acid at yeast-modified electrodes treated with vapours of EO with those obtained at electrodes without such treatment. Employing the responses of yeast-modified electrodes to L-lactic acid, the effect of vapours of Rh. tomentosum $\mathrm{EO}$ on the permeability of yeast $S$. cerevisiae cell walls was tested [13]. The data from the above study showed that the subjection of yeast cells to vapours of EO resulted in the 3 to 4 -fold increase of electrode responses due to the disruption of yeast cell membranes.

\section{ANTIOXIDANT ACTIVITY OF RH. TOMENTOSUM EOS}

The $\mathrm{ABTS}^{*+}\left(2,2^{\prime}\right.$-amino-bis(ethylbenzothiazoline6-sulfonic acid) diammonium salt) and $\mathrm{DPPH}$. (2,2-diphenyl-1-picrylhydrazyl) assays are com- monly used to evaluate the ability of present antioxidants in the matrix to scavenge free radicals.

A variation of antioxidant activities was evaluated among $R h$. tomentosum EOs samples from Samanis marsh (Utena District) depending on the plant vegetation stage [13]. The highest antioxidant activity was exhibited by young shoot EO (herbal material collected in June). It was concluded in the research that the older the plant, the lower the ability of EO is to scavenge free radicals (for shoot oils of the plants collected in September and October) [13].

\section{ANTI-INFLAMMATORY ACTIVITY OF RH. TOMENTOSUM EOS BY SUBCUTANEOUS CARRAGEENAN INJECTION-INDUCED HIND PAW OEDEMA TESTS}

The anti-inflammatory activity of two plant extracts - fraction obtained by supercritical fluid extraction (SFE) and EO extracted by hydrodistillation (HD) from the aerial parts of $R h$. Tomentosum - has been reporteded [16]. The extracts containing as the main compound palustrol 
(41.0-43.4\%), ledol (23.3-26.7\%) and ascaridole (4.5-15.1\%) showed an anti-inflammatory activity. The tests were evaluated by the subcutaneous carrageenan injection-induced hind paw oedema. The treated animals received essential oil (SFE and HD), the reference group received ketoprofen or piroxicam and the control group received $\mathrm{NaCl}$ $0.9 \%[16]$.

The results of the above study showed that the EOs enhanced a significant inhibition of oedema $50-73 \%$ for HD oil and $52-80 \%$ for SFE oil. These results were similar to those obtained with piroxicam (70\%) and ketoprofen (55\%). Rh. tomentosum essential oils extracted both by HD and SFE showed a significant anti-inflammatory activity as compared with non-steroidal anti-inflammatory drugs [16].

\section{TESTS OF TOXIC ACTIVITY OF RH. TOMENTOSUM EOS IN VIVO}

A toxicity test of the eight EOs (isolated from shoots and inflorescences; plant material collected in Samanis marsh (Utena District)) showed that the lethality $\mathrm{LC}_{50}$ and $\mathrm{LC}_{95}$ of brine shrimp (Artemia sera) larvae was $11.23-20.50$ and $34.00-76.07(\mu \mathrm{g} / \mathrm{mL})$, respectively [13]. In general, the data from the above study revealed that all $R h$. tomentosum EOs were notably toxic. Among them, EO obtained from shoots gathered in September (during the seed ripening stage) and containing appreciable amounts of palustrol $(26.0 \pm 2.5 \%)$, ledol $(21.5 \pm 4.0 \%)$ and ascaridole $(7.0 \pm 2.4 \%)$ appeared the most toxic. In contrary, inflorescence oil including almost the same quantities of palustrol (30.0 $\pm 1.6 \%)$ and ledol $(23.3 \pm 2.3 \%)$, but $10.1 \pm 1.3 \%$ of myrcene and insignificant amounts of ascaridole isomers was evaluated as less toxic [13].

Received 14 August 2020 Accepted 21 September 2020

\section{References}

1. Z. Gudžinskas, Vascular Plants of Lithuania, Publishing House of Institute of Botany, Vilnius (1999).

2. R. Popescu, B. Kopp, J. Ethnopharmacol., 147(1), 42 (2013) (and references therein).

3. A. Dampc, M. Luczkiewicz, Fitoterapia, 85, 130 (2013) (and references therein).
4. A. N. Shikov, O. N. Pozharitskaya, V. G. Makarov, H. Wagner, R. Verpoorte, M. Heinric, J. Ethnopharmacol., 154(3), 481 (2014).

5. E. A. Goun, V. M. Petrichenko, S. U. Solodnikov, et al., J. Ethnopharm., 81, 337 (2002).

6. N. A. Spiridonov, D. A. Konovalov, V. V. Arkhipov, Phytother. Res., 19, 428 (2005).

7. Z. Min, Z. Jing-jing, W. Wen-bin, Z. Yun, Z. Xinglei, Q. Wei-jing, Nat. Prod. Res. Dev., 22, 326 (2010).

8. M. V.Belousov, A. S. Saratikov, R. R. Akhmedzhanov, et al., Rast. Resursy, 42, 130 (2006).

9. D. Harbilas, L. C. Martineau, C. S. Harris, et al., Can. J. Physiol. Pharm., 8, 479 (2009).

10. L. A. Nistor Baldea, L. C. Martineau, A. BenhaddouAndaloussi, J. T. Arnason, É. Lévy, P. S. Haddad, J. Ethnopharmacol., 132, 473 (2010).

11. N. I. Belousova, S. E. Dmitruk, V. A. Khan, Khim. Farm. Zh., 23, 317 (1989).

12. C. Jin, W. Strembiski, Y. Kulchytska, R. G. Micetich, M. Daneshtalab, Daru, 7, 5 (1999).

13. A. Judzentiene, J. Budiene, J. Svediene, R. Garjonyte, Molecules, 25(7), 1676 (2020).

14. R. Butkienè, A. Judžentienè, J. Būdienè, A. Lugauskas, Conference 'Chemistry 2011' Book of Abstracts, Vilnius, Lithuania (2011).

15. R. Butkienè, A. Judžentienè, J. Būdienè, Conference of International Society of Chemical Ecology (ISCE 2015), Book of Abstracts, Stockholm, Sweden (2015).

16. S. Baananou, E. Bagdonaite, B. Marongiu, et al., Nat. Prod. Res., 29, 999 (2015).

17. H. Tunón, C. Olavsdotter, L. Bohlin, J Ethnopharmacol., 48, 61 (1995).

18. D. Kim, B. Nam, J. Food Sci. Nutr., 11, 100 (2006).

19. L. Zhang, Int. J. Food Nutr. Sci., 4, 8 (2017).

20. A. Jesionek, A. Kokotkiewicz, A. MikosikRoczynska, et al., Fitoterapia, 139, 104402 (2019).

21. M. V. Belousov, A. S. Saratikov, V. S. Tshichalin, et al., Rast. Resursy, 43, 126 (2007).

22. E. V. Basova, PhD Thesis, Tomsk State University, Tomsk, Russia (2004).

23. A. A. Narimanov, Radiobiologia, 32, 271 (1992).

24. A. A. Narimanov, S. N. Myakisheva, S. Kuznetsova, Radiobiologia, 31, 391 (1991).

25. T. G. T. Jaenson, K. Pålsson, A.-K. Borg-Karlson, Med. Vet. Entomol., 19, 345 (2005).

26. T. G. T. Jaenson, K. Pålsson, A. K. Borg-Karlson, J. Med. Entomol., 43, 113 (2006).

27. M. C. Egigu, M. A. Ibrahim, A. Yahya, J. K. Holopainen, Entomol. Exp. Appl., 138, 162 (2011).

28. A. Kuusik, M. Harak, K. Hiiesaar, L. Metspalu, U. Tartes, Termochim. Acta, 251, 247 (1995).

29. S. J. Himanen, Th. N. T. Bui, M. M. Mengistu, J. K. Holopainen, BMC Ecol., 15, 1 (2015).

30. Z. L. Xiu, X. L. Zhu, D. J. Zhang, J. Z. Yin, D. H. Wang, L. J. An, Chin. Sci. Bull., 48(16), 1718 (2003).

31. R. Butkienè, V. Šakočiūtè, D. Latvènaitè, D. Mockutè, Chemija, 19, 19 (2008). 
32. R. Butkiene, D. Mockute, J. Essent. Oil Res., 23, 9 (2011).

33. A. Judžentienè, J. Būdienè, A. Misiūnas, R. Butkienè, Chemija, 23(2), 131 (2012).

34. A. Judzentiene, R. Butkiene, J. Budiene, F. Tomi, J. Casanova, Nat. Prod. Commun., 7(2), 227 (2012).

35. Y. Holm, I. Laakso, H. Harmaja, R. Hiltunen, 24th International Symposium on Essential Oils, Final Programme, Abstracts, List of Participants, Berlin, Germany (1993).

36. T. Gretšušnikova, K. Järvan, A. Orav, M. Koel, Procedia Chem, 2(1), 168 (2010).

37. N. I. Belousova, V. A. Khan, T. P. Berezovskaya, V. L. Salenko, A. I. Velkov, S. E. Dmitruk, Rast. Resursy, 3, 81(1991).

38. D.-X. Zhao, H.-T. Wang, C.-S. Wu, S.-W. Sun, Y.-P. Ma, Busch. Acta Bot. Sinica, 29, 189 (1987).

39. Q. Zhi Guo, Y. Cheng Zeng, G. Xue Fei, M. Hui Yuan, J. Northeast Forest. Univ. 25(1), 41 (1997).

40. N. I. Belousova, V. A. Khan, T. P. Berezovskaya, Chem. Nat. Compd., 26, 398 (1990).

41. A. L. Shavarda, V. A. Khanin, N. A. Medvedeva, T. Y. Danchul, L. V. Shagova, Rast. Resursy, 40, 87 (2004).

Asta Judžentienė

\section{PELKINIO GAILIO (RHODODENDRON TOMENTOSUM HARMAJA (EX LEDUM PALUSTRE LINN)), AUGANČIO LIETUVOJE, ETERINIAI ALIEJAI IR JŲ SAVYBĖS}

\section{Santrauka}

Straipsnis apibendrina Lietuvoje augančio pelkinio gailio (Rhododendron tomentosum Harmaja (ex Ledum palustre Linn)) eterinių aliejų sudèties ir jų biologiškai aktyvių savybių (antioksidacinių, antifungicidinių, priešuždegiminių ir toksiškumo) tyrimus, per pastaruosius 15 metų publikuotus mokslineje spaudoje.

Pelkinis gailis (Rhododendron tomentosum Harmaja, anksčiau vadintas Ledum palustre Linn) yra visžalis, daugiametis krūmas, žydintis baltais ar rausvai bal- tais lipniais žiedais, kurie suformuoja žiedynus. Šis augalas (ex L. palustre var. palustre) auga ir Lietuvoje, dažniausiai kolonijomis (aukšta)pelkèse, durpynuose, spygliuočių miškuose, smèlinguose pajūrio pušynuose. Gailis turi aštrų specifini kvapą, kuris veikia centrinę nervų sistemą, gali sukelti vèmimą, galvos skausmus ar agresyvią elgseną. Pelkinio gailio preparatai yra plačiai naudojami liaudies medicinoje ir homeopatijoje; daugelis jo gydomujų savybių yra moksliškai patvirtintos. Šis augalas naudojamas žaizdų, egzemos ir kitu odos ligu gydymui, nuo ịkandimų, veikia raminamai, mažina reumato sukeltus skausmus, slopina uždegimus, spazmus, gydo peršalimo ligas, bronchitą, astmą, tuberkuliozę, stabdo kraujavimą ir kt.

Apibendrinti pelkinio gailio, augančio Lietuvoje (Rokiškio, Utenos, Vilniaus ir Šalčininkų rajonuose ir vienoje nenurodytoje augavieteje), jau ištirtų eterinių aliejų duomenys: cheminè sudètis bei biologinis aktyvumas. Aliejuose pagrindiniais junginiais nustatyti šie monoterpenai: p-cimenas, mircenas ir limonenas, biciklinis monoterpenoidas askaridolis ir oksiduoti seskviterpenai: ledolis, palustrolis bei ciklokolorenonai. Kai kuriuose aliejuose rasta nemažai heterociklinio junginio lepalolio. Didžioji dalis ištirtų lietuvišku gailių eterinių aliejų gali būti priskirti ledolis + palustrolis ar ledolis + palustrolis + askaridolis chemotipams.

Pateikti duomenys susiję su lietuviško pelkino gailio $R h$. tomentosum antifungicidiniu aktyvumu prieš Trichoderma harzianum, Penicillium cyclopium ir Candida parapsilosis, panaudojant agaro diskų difuzijos metodą, taip pat amperometriškai, naudojant Saccharomyces cerevisiae mielèmis modifikuotus elektrodus.

Priešuždegiminès lietuviško pelkinio gailio eterinio aliejaus savybès buvo ištirtos su laboratorinèmis žiurkèmis, stebint jų užpakalinių kojų patinimą (edemą), sukeltą atlikus karagenino injekciją i ́ paodị.

Pateikti publikuoti duomenys apie gailio eteriniu aliejų antioksidacines savybes, nustatytas su $\mathrm{ABTS}^{+}$, DPPH ir TROLOX reagentais, o toksinis aktyvumas - su krevečiu lervomis (Artemia sera). 